\title{
Information technologies and transformation of models for implementation of investment- construction projects in modern Russia ${ }^{a}$
}

\author{
Xeniya Malinina ${ }^{1}$, Juriy Shamara ${ }^{2 *}$, and Zhanna Petukhova ${ }^{3}$ \\ ${ }^{1}$ Saint Petersburg State University of Architecture and Civil Engineering, 190005 2-ya \\ Krasnoarmeiskaya st. 4, Russian Federation \\ ${ }^{2}$ Investment-Engineering holding "KNGK-Group", 350000 Budionnogo st. 117/1, Russian \\ Federation \\ ${ }^{3}$ Norilsk State Industrial Institute, 66330050 years of October st. 7, Russian Federation
}

\begin{abstract}
In this article we carry out the analysis of the possible directions and consequences of transformations of the existing models for implementation of investment-construction projects in relation with integration of information technologies and the construction industry in modern Russia. Such integration is considered as the most useful tool to solve such chronicle problems of the construction industry as low quality of works, missed deadlines and sustaining the best ratio "price-quality" for the customer. The basis for such integration is the technologies of informational modeling of construction objects. We investigated two basic models: disintegrated purchases and integrated purchases whose transformation will be directed towards development of mechanisms of partnership between participants of investment-construction projects, expanded use of "integrated" contracts in the system of state purchases of construction works and further centralization of control in the system of construction for state purposes.
\end{abstract}

\section{Introduction}

We will assume the digital economy as a business activity where the key factor for production is the data in the digital form, processing of large volumes of information and using the results of the analysis to significantly increase the efficiency of production and economic processes [1]. In the report of the Organization of the Economic Co-operation and Development (OECD) published in 2016 the conclusion is made that the digital economy is an unconditional imperative for the effective development of any sphere of human activity and will require, along with the introduction and mastering of information technologies, also a revision of the whole complex of production and, in a broader sense, social relations $[2,3]$. This topic is important in view of the "Strategy for Developing

\footnotetext{
${ }^{\mathrm{a}}$ The article was prepared as part of the work on the grant of the President of the Russian Federation NSh-4028.2018.6

*Corresponding author: info@kngk-group.ru
} 
Information Society in the Russian Federation for the Period 2017 - 2030" adopted in 2017 and the State program "Digital Economy of the Russian Federation" [4].

The investigation of the consulting company McKinsey "Digital Russia - a New Reality" published in July 2017 showed that the economic effect of digitalization of the economy in Russia can increase the GDP by 4.1-8.9 trillion rubles by the year 2025, which will constitute $19 \%$ to $34 \%$ of the total expected GDP growth [5]. In construction, the digital environment is formed on the basis of the technological platform based on the technology of informational modeling of construction objects (BIM technologies). A group of Russian researchers in the work "Digital Economy - Various Ways for Efficient Use of Technologies" showed that a very important characteristic of the digital environment in construction is the integrated character and openness of the information on the object for all the interested parties. This information is contained in the information model of a building (or facility) created during the projecting stage and utilized during construction and operation of the object [6]. The information model is integrated with the existing and prospective information systems supporting the construction, and, in the future, we should anticipate integration of technologies of information modeling of buildings with technologies of the distributed register, including the context of using "smart" contracts [7]. In general, according to the evaluation of Russian and foreign researchers, it is obvious that there is institutional and technological readiness of the construction industry in the developed countries for integration into the digital economy.

After analyzing the publications we can draw the conclusion that creating an allencompassing digital environment in the construction industry will significantly influence the investment-construction processes and the character of contract relationships between their participants. In this article we made an attempt to identify the basic directions of such influence and the possible consequences.

In the world practice, a few organizational-methodical approaches are used to implement the investment-construction process and regulate the contract relationships between their participants. In accordance with the classification by J. Masterman [8], there are two models to implement investment-construction projects (ICP). Each of them includes several schemes of interaction between their participants.

1) The model of disintegrated purchases implying distribution of responsibility for different types of project works between different workers, with each of whom a separate contract is signed (the designer makes the project, the subcontractor carries out construction, the engineer carries out designer's supervision etc.). The scheme of interaction within the framework of this model is called different names in different sources: "traditional" [9], "distributed" [10], the "projecting-tender-construction" scheme [11] and are primarily characterized by disintegration between the design and construction functions.

Within the framework of the described model, a "managerial contract" scheme is also used, when the general contractor only under the project management and outsources $100 \%$ of construction works to subcontractors.

2) The model of integrated purchases basing on the so-called "complex contract" implying integration of works carried out during various stages of the project, in the hands of one contractor, includes the following contract schemes:

- Project-construction contract (integration between designing and construction);

- "Turnkey" contract (the contractor takes on responsibility for the entire complex of works for designing and construction of the object and commissioning it to full capacity);

- "Engineering-Procurement-Construction-Management" contract (EPCM) (used for construction of high-tech industrial objects and means not only commissioning of a new plant but also transferring a new innovative technology); 
- A concession scheme based on complex contracts for designing, construction and operation of objects within the framework of the state-private partnership.

A brief comparative characteristic of models and schemes to implement investmentconstruction projects is shown in Table 1.

Table 1. A comparative characteristic of models and schemes to implement investment-construction projects.

\begin{tabular}{|c|c|c|c|c|}
\hline Scheme & Advantages & Drawbacks & Sphere of use & $\begin{array}{l}\text { Development } \\
\text { trend }\end{array}$ \\
\hline \multicolumn{5}{|c|}{ Disintegrated model } \\
\hline $\begin{array}{l}\text { Distributed } \\
\text { scheme }\end{array}$ & $\begin{array}{l}\text { Maximum economy } \\
\text { of invested money. } \\
\text { Highly controllable } \\
\text { parameters of the } \\
\text { project. } \\
\text { Even distribution of } \\
\text { risks between the } \\
\text { customer and } \\
\text { contractor. }\end{array}$ & $\begin{array}{l}\text { Loose coordination } \\
\text { between designing and } \\
\text { construction. } \\
\text { Significant growth of } \\
\text { the actual costs and } \\
\text { length of construction } \\
\text { works as compared to } \\
\text { the accepted ones. } \\
\text { High requirements for } \\
\text { the customer's expertise } \\
\text { level. }\end{array}$ & $\begin{array}{l}\text { Construction } \\
\text { for state } \\
\text { contracts. } \\
\text { Large } \\
\text { infrastructural } \\
\text { projects. }\end{array}$ & $\begin{array}{l}\text { Partial } \\
\text { integration of } \\
\text { designing and } \\
\text { construction. } \\
\text { Tighter co- } \\
\text { operation } \\
\text { between the }\end{array}$ \\
\hline $\begin{array}{l}\text { Managerial } \\
\text { contract }\end{array}$ & $\begin{array}{l}\text { High quality of } \\
\text { project management. } \\
\text { Not too high } \\
\text { requirements for the } \\
\text { customer's expertise } \\
\text { level. }\end{array}$ & $\begin{array}{l}\text { Insufficient } \\
\text { "transparency" and } \\
\text { controllability of works. }\end{array}$ & $\begin{array}{l}\text { Customers with } \\
\text { low managerial } \\
\text { expertise level. }\end{array}$ & \\
\hline \multicolumn{5}{|c|}{ Integrated model } \\
\hline $\begin{array}{l}\text { Design- } \\
\text { construction } \\
\text { contract }\end{array}$ & $\begin{array}{l}\text { Decreased risks for } \\
\text { the customer. } \\
\text { Not too high } \\
\text { requirements for the } \\
\text { customer's expertise } \\
\text { level. }\end{array}$ & $\begin{array}{l}\text { Insufficient } \\
\text { "transparency" and } \\
\text { controllability of works. } \\
\text { Relatively high costs. }\end{array}$ & $\begin{array}{l}\text { Commercial } \\
\text { construction. }\end{array}$ & $\begin{array}{l}\text { Better } \\
\text { controllability } \\
\text { of the project. } \\
\text { Tighter co- } \\
\text { operation } \\
\text { between the } \\
\text { parties of the } \\
\text { contract. }\end{array}$ \\
\hline $\begin{array}{l}\text { EPCM and } \\
\text { "turnkey" } \\
\text { schemes }\end{array}$ & $\begin{array}{l}\text { Low risks for the } \\
\text { customer. } \\
\text { Not too high } \\
\text { requirements for the } \\
\text { customer's expertise } \\
\text { level. } \\
\text { Implementation of } \\
\text { innovative } \\
\text { technologies. }\end{array}$ & $\begin{array}{l}\text { Insufficient } \\
\text { "transparency" and } \\
\text { controllability of works } \\
\text { and high costs of the } \\
\text { project. } \\
\text { Focusing on imported } \\
\text { technologies as } \\
\text { opposite to own } \\
\text { development. }\end{array}$ & $\begin{array}{l}\text { Industrial } \\
\text { construction } \\
\text { where the cost } \\
\text { of technologies } \\
\text { is much more } \\
\text { than the cost of } \\
\text { construction } \\
\text { and assembly } \\
\text { works. }\end{array}$ & \multirow{2}{*}{$\begin{array}{l}\text { Better } \\
\text { controllability } \\
\text { of the project. } \\
\text { Tighter co- } \\
\text { operation } \\
\text { between the } \\
\text { parties of the } \\
\text { contract. } \\
\text { Focusing on } \\
\text { flacquiring } \\
\text { experience and } \\
\text { localizing the } \\
\text { technologies. }\end{array}$} \\
\hline $\begin{array}{l}\text { Concession, } \\
\text { SPP-MPP }\end{array}$ & $\begin{array}{l}\text { Economy of budget } \\
\text { investment. } \\
\text { Increased quality of } \\
\text { state-controlled } \\
\text { works. }\end{array}$ & $\begin{array}{l}\text { Long-term risks. } \\
\text { Low "transparency" and } \\
\text { controllability of the } \\
\text { project. }\end{array}$ & $\begin{array}{l}\text { A wide range of } \\
\text { projects } \\
\text { implemented in } \\
\text { the public } \\
\text { sphere. }\end{array}$ & \\
\hline
\end{tabular}


As we can see in the table, the main trend of development of the investmentconstruction process, disregarding the selected model and scheme, is tendency for a deeper co-operation between the participants of investment-construction projects and a better transparency, controllability and, therefore, stability of the ICP. Implementation of information technologies into construction industry and using them as a basis for digital environment has the purpose to create pre-requisites for such co-operation, which, in its turn, will require transformation of the entire system of interaction between the participants of the ICP, that has already started and whose analysis for the two described models for implementation of investment-construction projects has made it possible to highlight the basic trends of this process, as presented below.

\section{The model of disintegrated purchases}

\subsection{Forming a mechanism of partnership between participants of investment-construction projects}

The term "partnership" means a documented co-operation between the customer and the contractor, and other participants of ICP, implying combination of their resources and effort to achieve the target of the project in the conditions of complete availability of information with the use of established rules and procedures that are mandatory for all the parties.

The technological basis for forming partnerships within the framework of an investment-construction project will be an informational model of the object of construction, which is an informational resource used by everyone and ensuring the capability for co-operative work of all the involved parties during the entire life cycle of the object. Partnership in the conditions of the digital environment can be supported by the following:

- Saving the investor's money due to co-operative use of the method of function-cost analysis;

- Decreasing the number of critical conflicts during implementation of ICP due to cooperative risk management;

- Decreasing the gap between designing and construction due to contractor's involvement in creating the information model of the object during the designing stage and organizing tight co-operation between the contractor and the designer during the construction stage;

During the last years, in the economy of Russia, including the construction industry, important changes have happened, which makes it possible to speak of a transition into a new quality from the viewpoint of forming conditions for wide use of digital technologies:

- Adopting a strategy of development of an informational society in the Russian Federation and the corresponding state program;

- Creating national and regional information systems (including the technical, software, organizational and professional support of their operation) in the sphere of state purchases (IIS SP), in the system of price-forming, including stock exchange of commodities for construction, in the system of overhaul and servicing of buildings and facilities, in the sphere of self-regulation etc.;

- Creating an institution of state technical customers providing professional support of investment-construction projects;

- Increasing the role of the Ministry of Construction and Housing as an institutional basis and the basic center of expertise in construction encompassing not only urban planning and construction for state purposes but also large-scale corporative construction 
projects in the sphere of industry and infrastructure development, as well as construction in the commercial production;

- Wide implementation of mechanisms of state-private partnership in the form of concession and gaining the corresponding experience in this sphere;

- Employing the professional community for regulating relationships in the industry (self-regulating through SRO, normative-technical regulating through updating the existing normative-technical documentation and creating new one etc.).

All these changes create material institutional and economic basis for transformation of the model of disintegrated purchases in the direction of forming partnerships between the participants of investment-construction projects.

\subsection{Management centralization in the system of construction for state purposes}

In accordance with the changes in the Urban-planning code of the RF, the key participant of the modern investment-construction process is the technical customer acting in the name of the developer and bearing full responsibility for efficient spending of investors' money, observing deadlines and ensuring the quality of construction. On the part of the state, efforts are made to centralize the activity of technical customers in the system of construction for sate purposes by forming a state structure of a new type - the universal technical customer (UTC) whose task is to ensure efficient spending of budget investment and increased quality of works. Using BIM technologies and integration of federal and regional information systems enforces this process due to creating an informationtechnological basis for efficient management of many projects at once.

\subsection{Intensifying the use of the managerial contract scheme}

Increasing the role of technical customers in the investment-construction process on the basis of digital technologies creates conditions for inclusion of technical customers into the system of general contract as general contractors, which will demand that they acquire the technical and technological expertise they currently do not have. This, in its turn, will create conditions for wide use of the managerial contract scheme that is very rarely used in modern Russia. An indirect indication of this trend is the explanation of the Ministry of Construction and Housing dated 28 April, 2017, saying that the function of the technical customer can only be fulfilled by a member of the corresponding self-regulating organization in the sphere of engineering research, architectural-construction designing, construction, reconstruction and overhaul of capital construction objects [12].

\section{The Model of Integrated Purchases}

\subsection{Increasing the transparency and controllability of integrated purchases that will result in their wider use in construction}

The model of integrated purchases implying transfer of responsibility for designing, construction and commissioning of the object to the contractor is primarily used in commercial and industrial construction. In the USA and Great Britain, more than $70 \%$ of ICP in these spheres are carried out within the framework of the integrated purchases model, whereas in Russia the share of such projects is as low as $40 \%$. Implementing the technology of informational modeling of construction objects on the basis of integrated databases on construction resources and universal methods of cost estimation in the Russian 
Federation will enable increased accuracy of cost calculation and better transparency and controllability of the investment-construction process for the customer. This will eliminate the existing obstacles for wider use of the integrated purchases mechanism: excessive cost of construction and non-transparency of spending the investors' money, and will create conditions for wider use of the corresponding schemes in construction in the RF.

\subsection{Expanding the use of the design-construction contract scheme onto the system of state purchases}

Due to the reasons described above, the design-construction contract scheme is very rarely used in the system of state purchases in the RF. However, considering the perspectives of a wider use of informational modeling and assuming quick development of the institution of the integrated technical customer in construction, who has managerial, engineering and often also construction expertise, as well as professional and technical resources in the sphere of digital technologies, we should anticipate expanded use of the designconstruction contract scheme in construction for state purposes. This will require changes in the effective legislature on state purchases (in particular, in federal laws No. 44 and No. 223, as well as in similar legal acts at the regional and municipal levels) in the parts regarding elimination or decreasing limitations imposed on combining lots in order to improve competitive advantage of the sales.

\subsection{Expanded use of the state-private partnership mechanism}

In the Russian Federation, the state-private partnership in construction is implemented in the form of concession for the objects in the state ownership, and in the form of the stateprivate and municipal-private partnership (SPP-MPP) for other objects. Currently, the stateprivate partnership has limited use, primarily in the sphere of transport infrastructure and residential areas development.

Implementing informational modeling technologies for construction objects to ensure efficient interaction between partners will make it possible to find the optimal balance between the parties' interests, decrease or eliminate long-term technical and financial risks for projects of this type while keeping their main advantages: increased efficiency of state investment and the quality of state-controlled works. This will create conditions for wider use of the state-private partnership mechanism in other spheres: construction and operation of schools, hospitals and social services objects.

\section{Conclusions}

Integration of the construction industry into digital economy will significantly influence the organization of the investment-construction process and will require transformation of the two existing models of implementation of investment-construction projects. Transformation of the disintegrated purchases model will be directed towards development of the mechanisms of partnership between participants of investment-construction projects; using "complex" integrated contracts in the system of state purchases of construction works; further centralization of management in the system of construction for state purposes through development of the institution of the integrated state customer. The model of integrated purchases will transform towards increased transparency of the investmentconstruction process, which will ensure its wider use in the system of construction for state and municipal purposes. 


\section{References}

1. Order of the President of the Russian Federation dated 09.05.2017 No. 203 "On the Strategy of Development of Informational Society in the Russian Federation for the Period 2017 - 2030"[online], Available at: http://kremlin.ru/ acts/bank/41919 (2017)

2. OECD "New Forms of Work in the Digital Economy", OECD Digital Economy Papers, No. 260, OECD Publishing, Paris [online], Available at: http://dx.doi.org/10.1787/5jlwnklt820x-en (2016)

3. OECD "Stimulating digital innovation for growth and inclusiveness: The role of policies for the successful diffusion of ICT", OECD Digital Economy Papers, No. 256, OECD Publishing, Paris [online], Available at: http://dx.doi.org/10.1787/5jlwqvhg3131-en (2016)

4. Order of the RF Government dated 28 July 2017 No. 1632-p on approving the program "Digital Economy of the Russian Federation" [online], Available at: http://static.government.ru/media/files/9gFM4FHj4PsB79I5v7yL VuPgu4bvR7M0.pdf (2017)

5. Digital Russia - a New Reality [online], Available at: https://www.mckinsey.com/ /media/McKinsey/Locations/Europe\%20and\%20Middle \%20East/Russia/Our\%20Insights/Digital\%20Russia/Digital-Russia-report.ashx (2017)

6. A. P. Dobrynin, K. Yu.Chernykh, V. P. Kupriyanovsky, P. V. Kupriyanovsky, S. A. Sinyagov, International Journal of Open Information Technologies, 4 (1)(2016)

7. N. Alekseyenko Block-Chain without Intermediaries: Development in the Digital Economy [online], Available at: https://realty.rbc.ru/news/59788fab9a7947d94ee1ddcb acts/bank/41919 (2017)

8. J. W. E. Masterman, An Introduction To Building Procurement Systems (E \& FN Spon, London, 1992)

9. A. E. Churbanov, Forming a Mechanism of Contract Relationships in Modern Construction (Saint Petersburg, 2006)

10. M. V.Demidenko, A. S. Philippov, Proceedings of Civil Engineering, 4 (57)(2016)

11. C. Hendrickson, Project Management for Construction (Carnegie Mellon University, Pittsburgh, 1999)

12. Ministry of Construction and Housing of the Russian Federation. Letter dated 28 April 2017 No. 15175-TB/02 [online], Available at: http://rulaws.ru/acts/Pismo-MinstroyaRossii-ot-28.04.2017-N-15175-TB 02/ (2017) 